\title{
The lizard cerebral cortex as a model to study neuronal regeneration*
}

\section{CARLOS LOPEZ-GARCIA, ASUNCION MOLOWNY, JUAN NACHER, XAVIER PONSODA, FRANCISCO SANCHO-BIELSA and GREGORI ALONSO-LLOSA}

\author{
Lab. Neurobiologia Celular, Facultad de Biologia, Universidad de Valencia \\ 46100 Burjasot, Valencia, Spain \\ Manuscript received on October 8, 2001; accepted for publication on October 15, 2001; \\ presented by Rosalia Mendez-OTERo
}

\begin{abstract}
The medial cerebral cortex of lizards, an area homologous to the hippocampal fascia dentata, shows delayed postnatal neurogenesis, i.e., cells in the medial cortex ependyma proliferate and give rise to immature neurons, which migrate to the cell layer. There, recruited neurons differentiate and give rise to zinc containing axons directed to the rest of cortical areas, thus resulting in a continuous growth of the medial cortex and its zincenriched axonal projection. This happens along the lizard life span, even in adult lizards, thus allowing one of their most important characteristics: neuronal regeneration.

Experiments in our laboratory have shown that chemical lesion of the medial cortex (affecting up to 95\% of its neurons) results in a cascade of events: first, massive neuronal death and axonal-dendritic retraction and, secondly, triggered ependymal-neuroblast proliferation and subsequent neo-histogenesis and regeneration of an almost new medial cortex, indistinguishable from a normal undamaged one. This is the only case to our knowledge of the regeneration of an amniote central nervous centre by new neuron production and neo-histogenesis. Thus the lizard cerebral cortex is a good model to study neuronal regeneration and the complex factors that regulate its neurogenetic, migratory and neo-synaptogenetic events.
\end{abstract}

Key words: medial cortex, hippocampus, postnatal neurogenesis, neural stem cells, zinc, regeneration.

\section{INTRODUCTION}

Sudden injuries to the nervous system (i.e., peripheral nerve section or fascicle tract insult after mechanical accidents) and slowly progressive neurotoxine lesions (i.e., excessive alcohol consumption) usually result in a permanent damage. When sectioned, fibre bundles re-grow until they re-innervate the proper muscles or nerve targets and restitute the functional performance. Then, we speak of "ner-

Correspondence to: Prof. Carlos Lopez-Garcia

E-mail: carlos.lopez@uv.es

Fax: ++3463864781

*Invited paper. vous" or "axonal" regeneration, which, of course, may occur preferentially when the lesion is done close to the terminal synaptic end, usually far away from the motoneurone cell body.

The concept of "neuronal regeneration" is reserved for the cases in which particular groups of lesioned/destroyed neurones are replaced by recently generated ones. This phenomenon has been well documented in some structures of the central nervous system of lower vertebrates and in some "peripheral" nervous centres (i.e. neurones in the olfactory mucosa and auditory hair cells of the macula) of mammals. The possibility that some "neu- 
ronal regeneration" could take place in the brain and spinal cord of higher vertebrates has an obvious importance. The possibility of manipulating and enhancing subjacent hidden regenerative potentialities gives some optimism for neural repair strategies. Even, transplantation of neural stem cells may also be a great contribution, provided that the stem cells reach the proper places and extend axons to the correct targets thus incorporating in the correct circuitry.

This study describes the phenomenon of neuronal regeneration of the lizard medial cerebral cortex. The lacertilian cerebral cortex may be regarded as an archicortex or "reptilian hippocampus", and its medial part as a "lizard fascia dentata" on grounds of their anatomy, cyto-chemoarchitectonics, ontogenesis and postnatal development. In normal conditions, the medial cortex of lizards shows delayed postnatal neurogenesis and growth during all the life span. Cells in the medial cortex ependyma proliferate and give rise to immature neurones, which migrate to the cell layer. This happens in adult lizards, in which the ependyma subjacent to the medial cortex remains as a residual neuroepithelium. Finally, the recruited neurones differentiate and give rise to zinc containing axons directed to the rest of cortical areas, thus resulting in a continuous growth of the medial cortex and its zinc-enriched axonal projection.

Perhaps the most important characteristic of the lizard medial cortex is that it can regenerate after being almost completely destroyed. Experiments in our laboratory have shown that chemical lesion of its neurones (up to 95\%) results in a cascade of events: first, those related with massive neuronal death and axonal-dendritic retraction and, secondly, those related with a triggered ependymal-neuroblast proliferation and subsequent neo-histogenesis and regeneration of an almost new medial cortex, indistinguishable from a normal undamaged one. This is the only case to our knowledge of the regeneration of an amniote central nervous centre by new neurone production and neo-histogenesis. Thus the lizard cerebral cortex is a good model to study neuronal regeneration and the complex factors that regulate its neurogenetic, migratory and neo-synaptogenetic events.

\section{THE CEREBRAL CORTEX OF REPTILES}

The cerebral cortex of reptiles appears formed by three principal areas: the medial, the dorsal and the lateral cortex. In all the cortical areas most neuronal cell bodies are grouped forming a principal cell layer sandwiched between the inner and outer plexiform layers, which are populated by scarce interneurons and where the afferent connections terminate in a highly laminated fashion (Fig. 1A-C).

Golgi impregnations (Fig. 1D) have shown that the principal neurones are long axon projection neurones with spiny bipyramidal and "double bouquet" bitufted dendritic trees (De la Iglesia and Lopez-Garcia 1997a). On the other hand, interneurons located in the plexiform layers are short axon neurones with non-spiny or sparsely spiny dendrites displaying diverse morphologies (De la Iglesia et al. 1994, (De la Iglesia and Lopez-Garcia 1997b, Bernabeu et al. 1994). Most local interneurons are GABA-immunoreactive (Lopez-Garcia et al. 1988 a, Schwerdtfeger and Lopez-Garcia 1986) and display either parvalbumin (Fig. 1E), calbindin, or calretinin immunoreactivities (Martinez-Guijarro et al. 1991a, Martinez-Guijarro and Freund 1992) as well as a wide spectrum of neuropeptide immunoreactivities (Davila et al. 1991) or even NADPH diaphorase/ NOS synthetase (Davila et al. 1995).

In addition to the pattern of extracortical afferences and efferences (Bruce and Butler 1984), the intracortical scheme of connections of the lizard cerebral cortex also has a clear resemblance to that of the mammalian hippocampus and the entorhinalolfactory cortex (Olucha et al. 1988).

The lateral cortex receives the bulk projection from the principal olfactory bulb and may be considered homologous to the mammalian olfactory cortex (Hoogland and Vermeulen-Vanderzee 1995, Martinez-Garcia et al. 1986). It emits a highly laminated axonal projection to the medial cortex (Fig. 

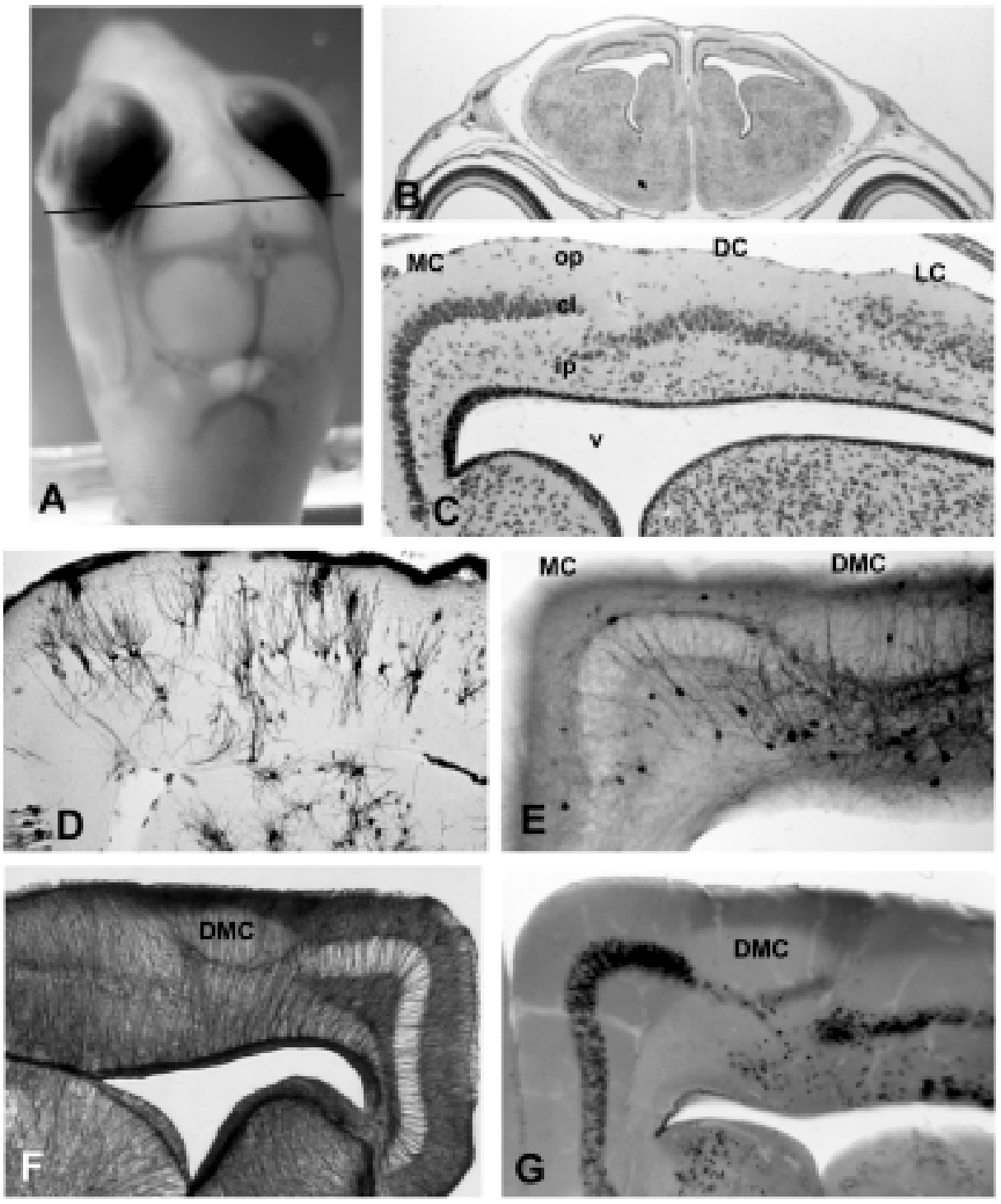

Fig. 1 - The lizard cerebral cortex. A: Dorsal view of the head of a lizard embryo showing the two telencephalic vesicles between the two pigmented eyeballs and the two posterior mesencephalic vesicles (optic tecta). B: Transversal section to the telencephalon of the lizard embryo in the plane signalled by the line in A. C: Idem, enlarged aspect of the right hemisphere; observe most neuronal somata grouped in conspicuous cell layer (cl) sandwiched between the inner (ip) and the outer (op) plexiform layers. D: Golgi impregnated transversal section showing the bitufted aspect of the lizard cortex principal neurones. E: Parvalbumin immunostained section showing positive interneurons in the plexiform layers and a dense plexus of immunopositive axons surrounding the cell layer of the dorsomedial cortex. F: Glial fibrillar acidic protein immunostaining in the lizard cerebral cortex; observe the scaffold of radial ependymal processes which delineate most lizard cortex subregions. G: Transversal section of the lizard cortex immunostained for C-Fos showing positive nuclei in most principal neuronal somata of the principal cell layers (i.e., they are very active) nevertheless, those of the dorsomedial cortex appear negative (i.e., likely due to the intensive parvalbumin-GABA perisomatic inhibitory input as seen in E). (DC - dorsal cortex; DMC - dorsomedial cortex; LC - lateral cortex; MC - medial cortex) (Scale bar represents $1 \mathrm{~mm}$ in A, $500 \mu \mathrm{m}$ in B, $200 \mu \mathrm{m}$ in $\mathrm{C}$ and $150 \mu \mathrm{m}$ in $\mathrm{D}, \mathrm{E}, \mathrm{F}$ and $\mathrm{G})$. 
Fig. 2 - The lizard medial cortex connections. A: Horseradish peroxidase (HRP) anterograde labelling of the outermost strata of the outer plexiform layer ("lizard perforant path") of the medial cortex after HRP injection in the ipsilateral lateral cortex, B: HRP anterograde labelling of the medial cortex cell layer juxtasomatic strata after massive injection of HRP in the contralateral hemisphere ("lizard commissural path"); notice also the heavy retrograde labelling of the principal neurones of the dorsomedial cortex and those of the medial edge of the dorsal cortex. C: Intracellular injection of HRP in a principal neurone of the dorsomedial cortex which emits a commissural axon. D: Idem, enlarged view of the injected neurone showing its bipyramidal aspect. E: Timm stained (for vesicular zinc) and toluidine blue counterstained lizard cortex transversal section showing the vesicular zinc enriched fields as dark zones where metallic silver has been precipitated. F-G: Idem, one micron semithin section roughly showing a zone marked by a square in E; observe the punctate appearance of the Timm reaction in the plexiform layers. H: Electron microscope aspect of the Timm reaction; silver granules appear grouped onto some presynaptic boutons. I-J: Timm positive presynaptic boutons as seen after sulphide-osmium treatment for zinc detection; observe the electrondense zinc precipitate inside synaptic vesicles and the big size of boutons which synapse dendritic spines and may completely surround them. (Scale bar represents $100 \mu \mathrm{m}$ in A, $150 \mu \mathrm{m}$ in B, $300 \mu \mathrm{m}$ in C, $75 \mu \mathrm{m}$ in $\mathrm{D}, 400 \mu \mathrm{m}$ in $\mathrm{E}, 100 \mu \mathrm{m}$ in $\mathrm{F}, 40 \mu \mathrm{m}$ in $\mathrm{G}, 5 \mu \mathrm{m}$ in $\mathrm{H}, 2 \mu \mathrm{m}$ in $\mathrm{I}$ and $3 \mu \mathrm{m}$ in $\mathrm{J})$.

2A) a projection that can be considered as a "lizard perforant path" in comparison to that of the mammalian perforant path arising from the entorhinal cortex and ending in the hippocampus and outer molecular layer of the dentate gyrus.

The dorsal cortex seems to be an area of thalamic polysensorial convergence; its medial and lateral edges overlap the dorsomedial and lateral cortices giving rise to the "superpositio medialis" and "superpositio lateralis", respectively (de Lange 1911, Kappers and Theunissen 1908) in which some classic authors intended to detect the primordium of neocortex in reptiles (Edinger 1896, Elliot-Smith 1903, Johnston 1916). However, in lizards a primordium of hippocampus may be better recognised in the medial to dorsal areas (Lacey 1978) whereas in the dorsal to lateral areas a transition from CA3CA2-CA1 hippocampal areas to olfactory cortex in the anterior levels and to the subiculum in the posterior levels has been hypothesised (Lopez-Garcia et al. 1992).

A fourth cortical area can be recognised in lacertilian reptiles: the lizard dorsomedial cortex or "zona piramidal curvilinea" (Ramon and Cajal 1917). This area has been considered homologous to the CA3 area of the hippocampus because it emits a prominent commissural-contralateral projection (Fig. 2B-D) (Martinez-Guijarro et al. 1990) and because it is the main recipient of the zinc positive "lizard mossy fibres" coming from the medial cortex (Lopez-Garcia and Martinez-Guijarro 1988, Martinez-Guijarro et al. 1984) (Fig. 2B-C).

The lizard medial cortex receives axonal projections from the lateral olfactory cortex: the "lizard perforant path" and emits a prominent glutamatergic zinc-enriched axonal projection to the ipsilateral dorsal and dorsomedial cortices, as well as to the dorsal septum, that conforms the "lizard hippocampal mossy fibre system"' (Fig. 2E-J) (LopezGarcia et al. 1983a, Martinez-Guijarro et al. 1987, Martinez-Guijarro et al. 1991b, Molowny et al. 1987). These axons give rise to big boutons that synapse onto the dendritic spines of bipyramidal neurones in the dorsomedial and dorsal cortices (Martinez-Guijarro et al. 1984) conforming a kind of hypertrophied "lizard stratum lucidum" (Fig. 2C, E).

Concurrence of zinc histochemical staining and glutamate-immunoreactivity in the medial cortex axonal projection (Martinez-Guijarro et al. 1991b) and in the hippocampal mossy fibre boutons adds further support to the presumed homology of the lizard medial cortex and the mammalian fascia dentata (Lopez-Garcia et al. 1983b, Molowny and Lopez-Garcia 1978). Nevertheless, the main support for the homology between the medial cortex of liz- 

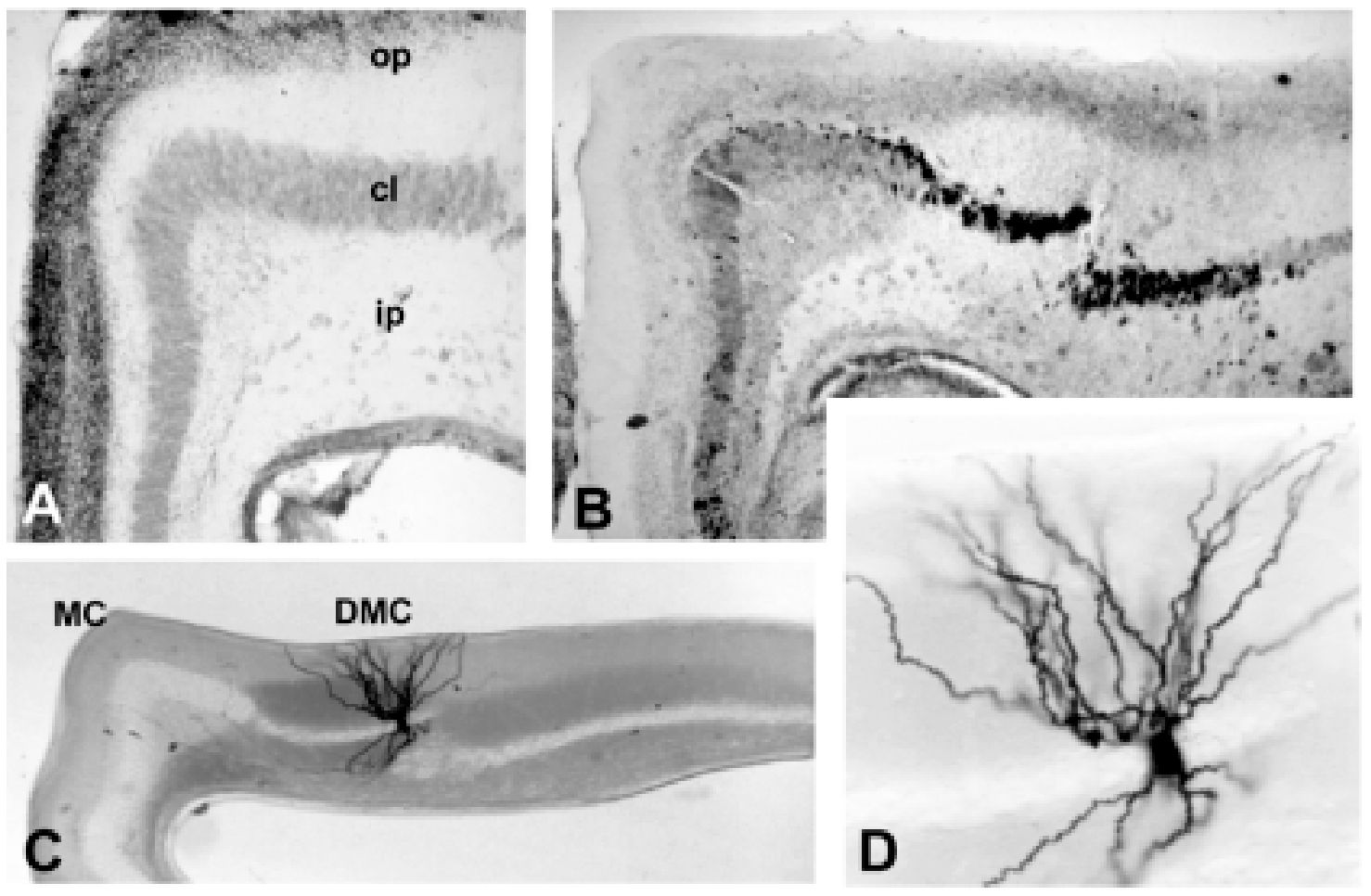

D
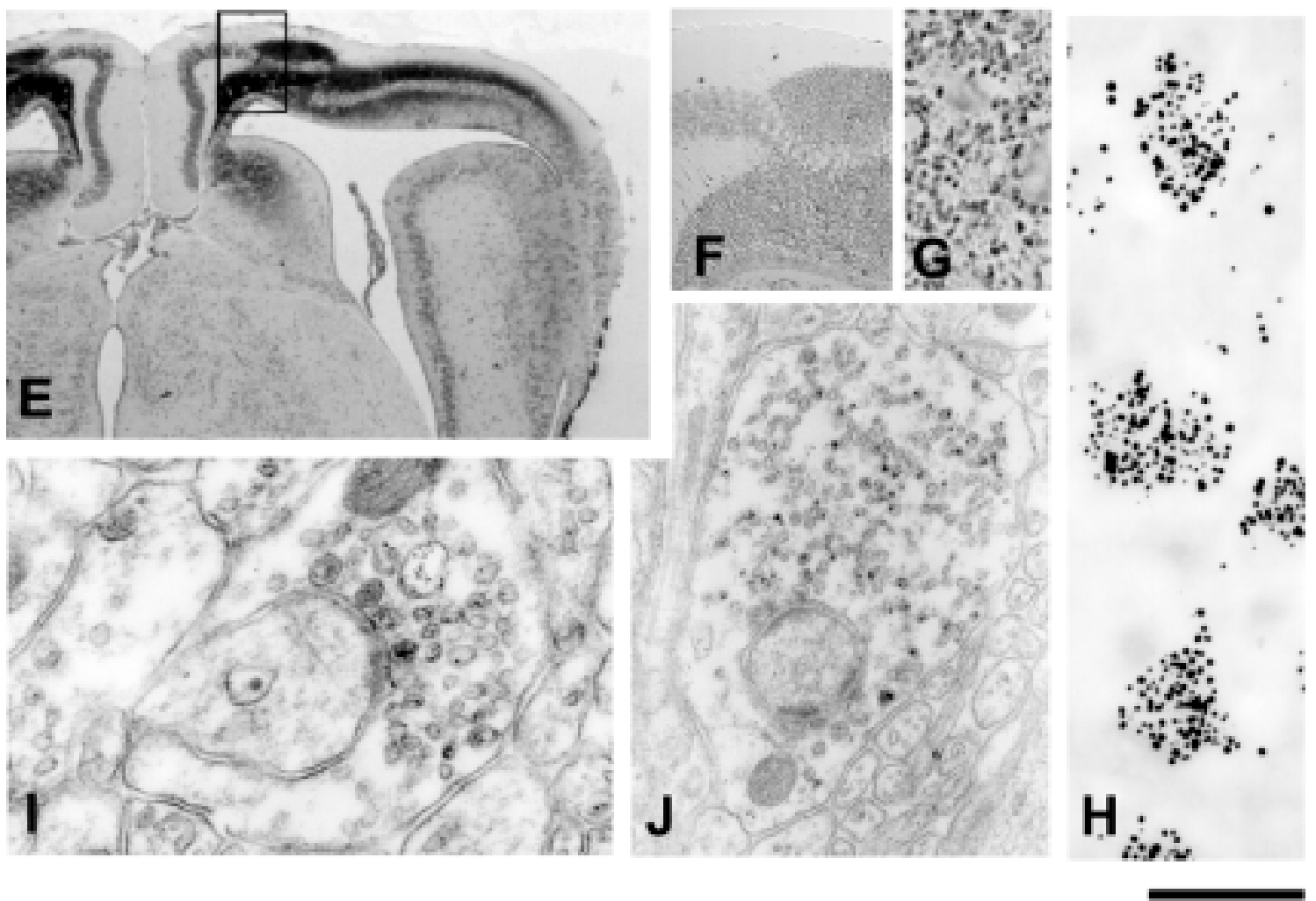
ards and the mammalian fascia dentata comes from their common ontogenetical characteristics, primarily a continued late postnatal neurogenesis.

\section{POSTNATAL GROWTH}

The volume of the cortical zinc-positive synaptic fields increases dramatically with age in lizards (Perez-Cañellas 1989, Rodriguez-Serna 1987). Quantitative stereological studies have demonstrated that this volumetric increase is paralleled by a significant increase of the number of zinc-positive synapses in the same areas (Fig. 3A-C) (Rodriguez-Serna 1987).

In the lizard cortex the number of medial cortex granule cells giving rise to zinc positive boutons increases with age (Lopez-Garcia et al. 1984), while the number of target neurones (mainly bipyramidal neurones) does not increase significantly. The bipyramidal neurones do, however, extend their dendritic tree, hence creating new potential target areas for zinc positive boutons (Martinez-Guijarro 1982). A similar phenomenon occurs in the inner ear of lower vertebrates, where the number of inner hair cells increases postnatally without being paralleled by an increase in spinal ganglion neurones (Corwin 1985) and also in the mammalian hippocampus where there is a continued addition of neurones to the fascia dentata but not to its target area, i.e., pyramidal neurons of CA3 (Bayer et al. 1982, Bayer 1982).

The dendritic growth of bipyramidal neurones seems to occur in the soma-proximal dendritic segments (Martinez-Guijarro 1985). This juxtasomatic dendritic zone of the dorsomedial cortex bipyramidal neurones ("lizard stratum lucidum') could attract the incoming axons. Presently there is no direct evidence on the guiding mechanism/s of the new zinc positive axons. In their initial trajectory they may take advantage of the already present fasciculated axons, as seen in the electron microscope. Finally, the new incoming axons may contact new dendritic spines generated in the juxtasomatic dendritic segment of bipyramidal neurones, which probably correspond to the zone displaying NGF immunoreactivity (Lopez-Garcia et al. 1992), or even interact with pre-existing boutons. The presence of filopodial growth cone-like profiles in immature zinc positive boutons that appear randomly distributed within the wide zinc-reactive zones of the plexiform layers accounts for this possibility.

The biological meaning of the continuous growth of the zinc rich axonal system in lizards is an enigma. It is involved in lizard spatial memory performance (Font et al. 1989) like the hippocampal mossy fibers in mammals. Perhaps the continuous growth of the medial cortex of lizards, allowing an increase of spatial memory performance, fits well with the age related increase of territorial domains observed in lizards (Schrener and Schrener 1982).

\section{POSTNATAL NEUROGENESIS}

Early observations on the dramatic increase in the neuronal population of the medial cortex during the life span of lizards, prompted us to study the origins of the newly generated neurones by using the available markers of cellular proliferation, i.e., tritiated thymidine and autoradiography (Lopez-Garcia et al. 1988b). Short survival times after the marker injection resulted in labelling cells located in the ependyma (Fig. 3D); no labelled cell was observed in the nervous parenchyma. Longer survival times (up to four weeks) resulted in labelling cells located both in the ependyma and in the medial cortex cell layer (Fig. 3E), thus indicating a migration from the germinative zone. Effectively, intermediate survival times resulted in labelling migratory neurones through the inner plexiform layer of the medial cortex (Fig. 3F-I)

Postnatal neurogenesis in the medial cortex has been demonstrated in perinatal, young and adult lizards. In fact, the generation of neurones appears to persist throughout the entire life span of individuals, although aging implies a decrease in the generative potential of the subjacent ependyma (LopezGarcia et al. 1988c). Despite the fact that postnatal neurogenetical activity is subject to seasonal varia- 

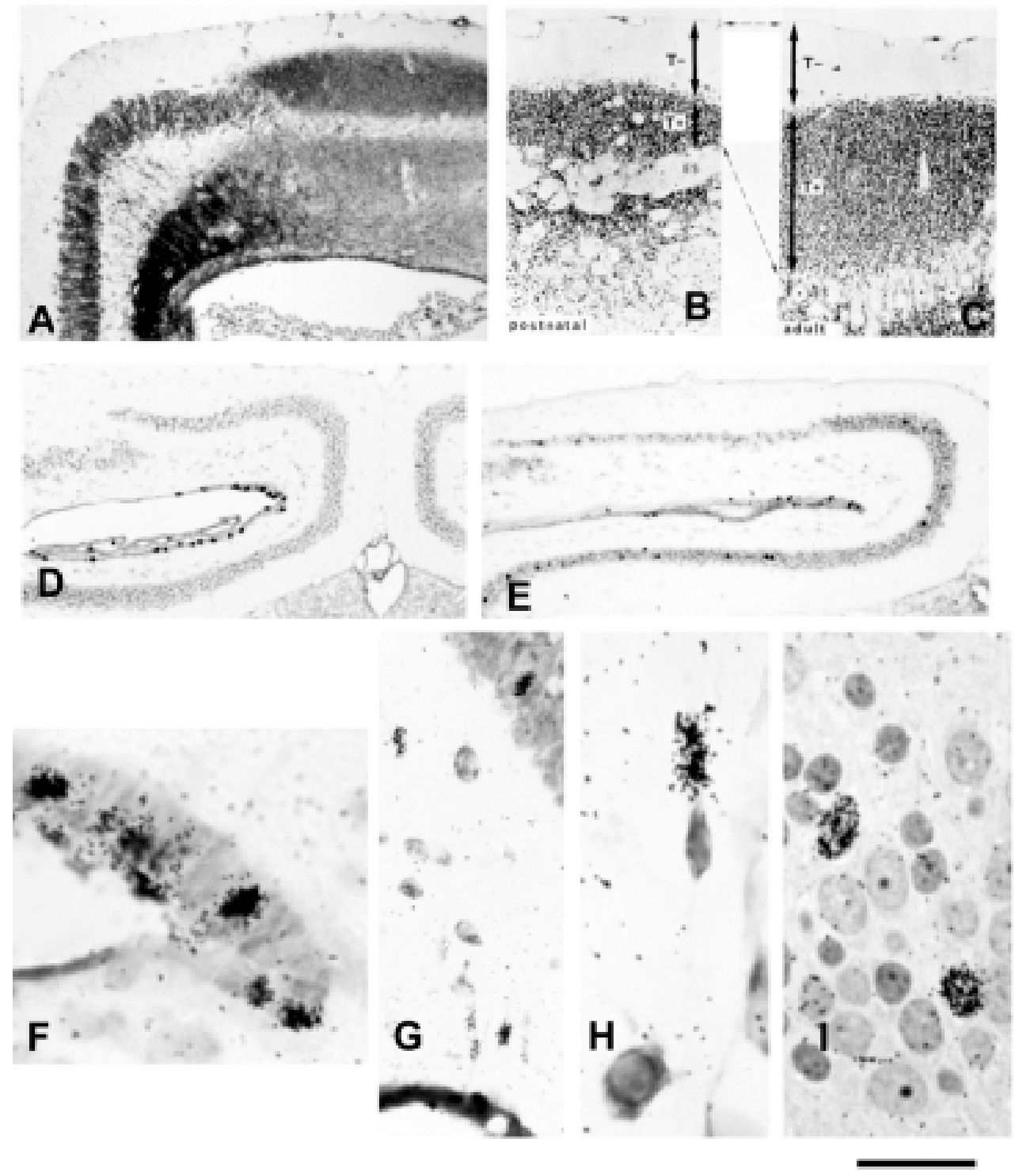

Fig. 3 - Postnatal growth of the lizard medial cortex. A: Lizard cortex transversal section (selenite method) showing both the zinc enriched fields of boutons as well as their parent neurones in the medial cortex cell layer after retrograde labelling of selenium-zinc complexes generated by intraperitoneal injections of sodium selenite five days prior the sacrifice. B-C: aspect of the dorsomedial cortex outer plexiform layer in a postnatal and an adult lizard; observe the increase in the thickness of the zinc positive stratum (T+) ("lizard stratum lucidum") in the adult and the similar thickness of the outer zinc negative (T-) stratum. D: Autoradiography and toluidine blue counterstaining of a lizard cortex transversal section injected with tritiated thymidine one day before sacrifice; observe the presence of labelled cells in the ependyma. E: Idem, one month after tritiated thymidine injection; observe the presence of labelled cells both in the medial cortex cell layer and also in the ependyma. F: Idem, enlarged view of the medial cortex ependyma (sulcus septoarchicorticalis = septomedialis) one day after tritiated thymidine pulse. G: Idem, one week after tritiated thymidine pulse showing several labelled cells crossing the inner plexiform layer. H: Idem, enlarged aspect of a migratory fusiform labelled cell in the inner plexiform layer. I: Idem, semithin section of the medial cortex cell layer, one month after the tritiated thymidine pulse, showing two labelled nuclei. (Scale bar represents $200 \mu \mathrm{m}$ in A, $100 \mu \mathrm{m}$ in B and C, $300 \mu \mathrm{m}$ in D and E, $50 \mu \mathrm{m}$ in G and $20 \mu \mathrm{m}$ in F, H and I). 
tions (Ramirez et al. 1997), it results in quadrupling the number of neurones in the medial cortex (LopezGarcia et al. 1984) over the normal life span (about five years) (Caetano et al. 1986) of the common lizard Podarcis hispanica.

In rodents, the fascia dentata has extensive postnatal neurogenesis, acquiring up to $85 \%$ of its neurones during the first three postnatal weeks (Bayer 1980). Later, additional neurones are recruited along life span but specially during the juvenile periods of life (Bayer et al. 1982, Kaplan and Bell 1983). In primates, there is even more delay in the ontogenesis of their fascia dentata as postnatal neurogenesis continues for the first three postnatal months (Eckenhoff and Rakic 1988, Rakic and Nowakowski 1981, Kornack and Rakic 1999).

\section{THE LIZARD NEURAL STEM CELLS AND THE EPENDYMAL SULCI}

Cells labelled with DNA precursors may be observed throughout the lateral ventricle ependymal surface, being especially abundant in specific areas displaying pseudo-columnar appearance: the sulci, appearing as regions in which residual embryonary neuroepithelium still remains. Our studies with proliferation markers indicate that some ependimary cells can suffer asymmetric divisions and give rise to a cell that differentiates and incorporates to the brain parenchyma, while the other remains in the ependyma. This later cell may divide again under the proper circumstances and thus can be considered a neuronal stem cell. Actually, there is no structural evidence which permits to identify neural stem cells in the ependyma.

There are four main sulci in the lateral ventricles of reptiles: the sulcus septo-archicorticalis (=septo-medialis), the sulcus lateralis, the sulcus ventralis and the sulcus terminalis (Fig. 4) (Kirsche 1967, Tineo et al. 1987).

Based on its anatomical location and their postnatal neurogenetical potentiality, the sulcus ventralis can be related to the anterior subventricular zone of the mammalian brain (Altman 1969, Luskin 1993). The cells generated there migrate longitudinally un- til the olfactory bulb (Peñafiel et al. 1996), where they differentiate and become incorporated in the olfactory bulb circuitry.

On the other hand, the sulcus septoarchicorticalis may be related to the posterior archicortical matrix zone of the hippocampal fascia dentata (Altman and Bayer 1990) which, in mammals, has lost its ventricular connection. In the medial cortex of lizards of all ages, the sulcus septoarchicorticalis is the germinative center for the continued postnatal neurogenesis (Lopez-Garcia et al. 1988b, LopezGarcia et al. 1988c).

No counterpart in mammals has been found neither for the sulcus lateralis, which would be engaged in the postnatal growth of the olfactoryentorhinal cortex, nor for the sulcus terminalis, which could be related with the postnatal growth of subcortical structures: dorsal ventricular ridge and the nucleus sphericus (Perez-Sanchez et al. 1989), two anatomical areas characteristic of the reptilian telencephalon.

\section{MIGRATION AND MATURATION OF NEWLY GENERATED NEURONES}

The fate of the newly generated neurones in the ependyma seems to be migration: to the olfactory bulb when produced in the sulcus ventralis, or to the medial cortex cell layer when produced in the sulcus septo-archicorticalis. The fate of the cells produced in the other sulci or any other ependymal area remains unknown. Whether newly generated cells in other ependymal areas may undergo cell death (Johnson and Deckwerth 1993) or may incorporate into the brain parenchyma still remains to be elucidated.

Either radial or tangential migrations seem to be favored by the presence of residues of polysialic acid (PSA) on the neural adhesion molecule (NCAM). This molecule confers the neurone and neurites anti-adhesive properties and allows them to move through the nervous parenchyma (Rutishauser and Landmesser 1996). In the lizard cerebral cortex PSA-NCAM is intensely expressed in all the regions with presumed migratory activity (unpublished ob- 

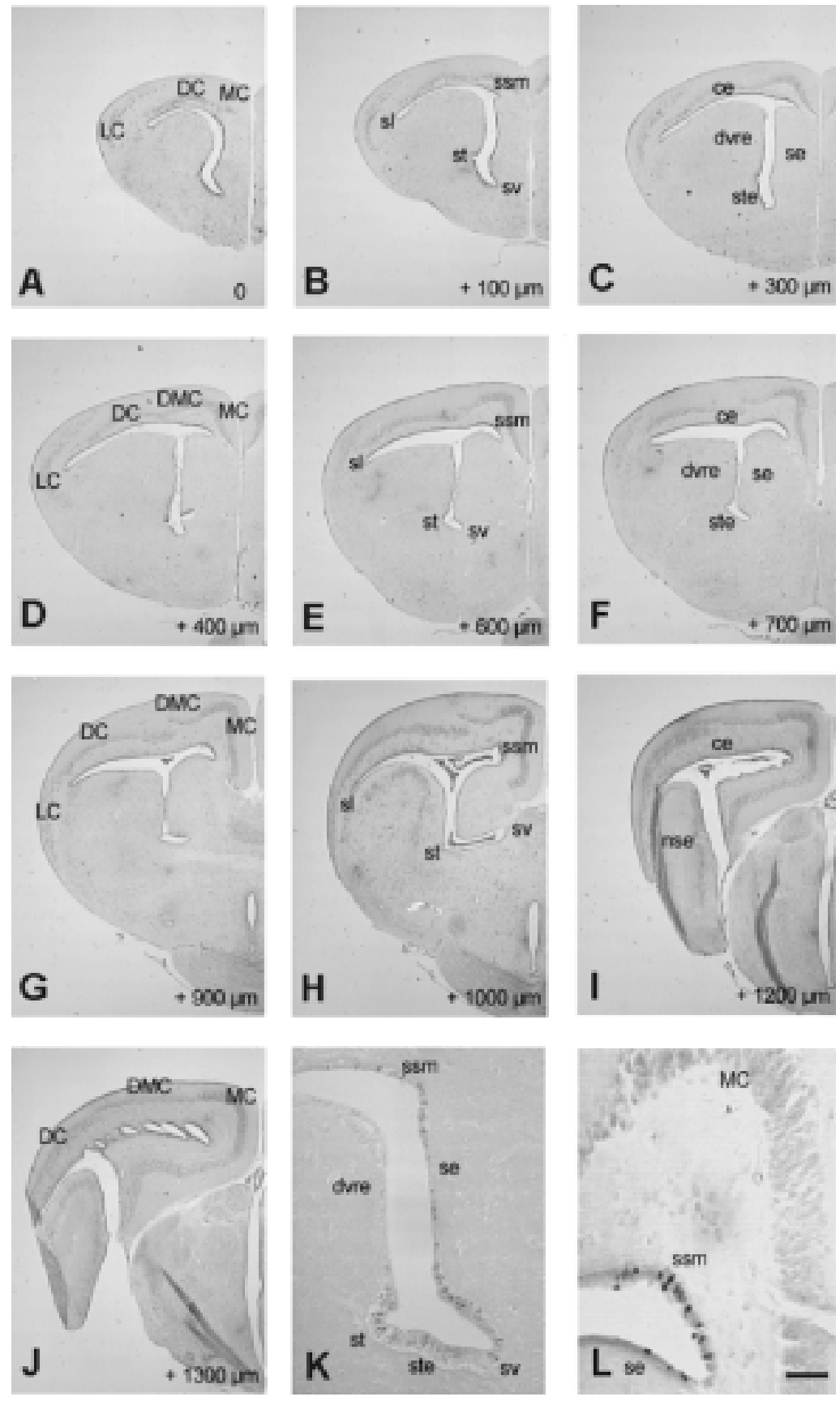

Fig. 4 - Transverse sections of the left hemisphere of Podarcis hispanica. A-J: Morphology of ten equidistant sections from rostral (A) to caudal (J) levels showing the position of cortical areas (MC: medial cortex; DMC: dorso-medial cortex; DC: dorsal cortex; LC: lateral cortex), ependymal sulci (ssm: sulcus septomedialis; sl: sulcus lateralis; st: sulcus terminalis; sv: sulcus ventralis) and intersulcal ependymal areas (ce: cortical ependyma; dvre: dorsal-ventricular ridge ependyma; ste: striatal ependyma; se: septal ependyma; nse: nucleus sphericus ependyma). K: enlarged aspect of the ependyma at the level of B showing the complex formed by the sulcus terminalis plus the sulcus ventralis and the striatal ependyma. L: enlarged aspect of the sulcus septomedialis at level G showing some PCNA labelled cells. (Scale bar represents $200 \mu \mathrm{m}$ in A-J and $30 \mu \mathrm{m}$ in K-L). 
servations). In the adult mammalian hippocampus PSA-NCAM expression is mainly located in a subpopulation of granule cells located in the innermost region of the granular layer of the dentate gyrus (Seki and Arai 1991). Many of these cells are recently generated neurones (Seki and Arai 1993), which could be migrating to upper rows of the granule cell layer or extending their projections.

In the sulcus septo-archicorticalis, the newly formed neurones are guided by radial ependymocytic glia in their migration to the granular cell layer of the lizard medial cortex (Garcia-Verdugo et al. 1986). This guiding mechanism appears to be similar to that observed during the histogenesis of the dentate gyrus in monkeys (Eckenhoff and Rakic 1984). A well developed vertical radial glia network persists in the medial cortex of adult lizards (Fig. 1F). Although the adult hippocampus lacks a radial glial scaffold, some radial glia-like cells still persist in the dentate gyrus (Cameron et al. 1993, Rickmann et al. 1987), and probably are implicated in the short-distance migration and dendritic development of newly generated granule cells (Seki and Arai 1999).

In both the lizard medial cortex and the mammalian fascia dentata, neurones generated during adulthood differentiate and successfully complete axonal growth to their specific targets. In youngadult rats newly generated granule neurones extend axons that reach the zinc-positive stratum lucidum of the CA3 hippocampal region (Stanfield and Trice 1988, Hastings and Gould 1999). In adult lizards, the postnatally generated neurones differentiate into ultrastructurally normal neurones and extend their axons to the normal target areas in the zinc-enriched synaptic fields of the cortex (Lopez-Garcia et al. 1990a). It is likely that new neurones participate in the formation of trace memories (Gould et al. 1999, Shors et al. 2001) and thus increase spatial memory performance.

\section{A WORKING HYPOTHESIS}

It is commonly accepted that the regenerative capacity of different nervous centers depends on whether they have finished their neurogenetical schedules. Fishes show postnatal neurogenesis in their spinal cord and they can regenerate it after transection (Lurie and Selzer 1991). This regenerative phenomenon is age-dependent (Berstein 1964). In larval frogs, spinal cord transection leads to regenerative events that restore the control of initial movements, but spinal cord transection in adult frogs leads to final impairment of movement (Holder and Clarke 1988). In the same way, spinal cord transection in chick embryos leads to regeneration, provided that it is done before day E15 (Shimizu et al. 1990). According to these precedents, the delayed postnatal neurogenesis of the lizard cortex should result not only in enhanced behavioral performance but in an extraordinary regenerative ability.

\section{NEUROTOXIC LESION OF THE LIZARD MEDIAL CORTEX}

After initial trials with several neurotoxins, specific lesions of the lizard medial cortex were successfully performed after intraperitoneal injections of 3 -acetylpyridine (3AP). Up to $90-95 \%$ of the medial cortex neurones are destroyed, leaving intact or only slightly affected the rest of brain structures (Font et al. 1991, Lopez-Garcia et al. 1990b).

As early as twelve hours after 3AP injection, neuronal cell bodies in the medial cortex show initial degenerative symptoms, like cytoplasm vacuolization and nuclear chromatin condensation (Fig. 5AF). Degeneration progresses until days 4-10 after the 3AP injection, at which time the medial cortex cell layer contains up to $95 \%$ pyknotic cell nuclei in severely affected specimens (Fig. 5G-H). Moreover, the zinc positive boutons arising from the medial cortex show swelling and destruction as observed in the electron microscope (Fig. 7F).

After 3AP administration some scattered cells in the cell layer of the medial cortex remain unaffected (Fig. 5E-H). They are 3AP-resistant neurones 
that may be the origin of a remaining population of zinc positive boutons in the cortex.

3AP lesioned lizards display behavioral disorders like lack of prey-catch fitness, intense exploratory movements, and impairment in their performance in a maze test. These symptoms are interpreted as a severe disruption of their spatial memory (Font et al. 1989). The lesioned animals do, however, progressively recover all their initial behavioral abilities after several weeks.

\section{REGENERATION OF THE MEDIAL CORTEX}

The use of tritiated thymidine $\left({ }^{3} \mathrm{HT}\right)$ and 5-bromodeoxiuridine ( 5 ' - BrDu) as markers of cell proliferation reveals that $3 \mathrm{AP}$ intoxication triggers a proliferative burst in the medial cortex ependymary sulcus. The proliferative burst or "reactive neurogenesis" lasts from day 2-3 to day 7 after 3AP injection and shows itself as a highly regulated mitotic response against the lesion (Molowny et al. 1995). Labelled cells are located exclusively in the juxtaependimary region if the survival time after the cell proliferation marker pulse is one day. Increased survival times after ${ }^{3} \mathrm{HT}$ or $5^{\prime}$-BrDu pulses result in labelled migratory cells appearing in the inner plexiform layer or even within the granule cell layer (Fig. 6A-E).

In the electron microscope or even by light microscopy on semithin sections, signs of a restorative process are seen at days 4-10 after 3AP injection (Fig. $5 \mathrm{G}-\mathrm{H}$ ), including the presence of abundant immature migratory neurones in the medial cortex inner plexiform layer. As time progresses, increasing numbers of immature cell bodies accumulate in the medial cortex granule cell layer. These newly generated cells progressively replace the dead/pyknotic neurones. Recovery of the normal histological appearance progresses during two-three months (Fig. $5 \mathrm{I}-\mathrm{K}$ ). Thereafter (Figs. 5L, 6F), neither pyknotic nuclei nor cellular debris are seen in the medial cortex cell layer. The only residual symptoms of the 3AP induced degeneration are the presence of abundant lysosome-like dense bodies accumulated in the ependymary cell somata.
Resorption of cellular debris and demolition of the lesioned cellular network is a long and complex process hold by two main cellular populations: ependymocytic-astroglial-like cells and microglia. Initially, the ependymocytic- astroglial-like expansions that form the blood-brain barrier (Garcia-Verdugo et al. 1981) in the lizard cortex are the principal agents in debris removal (Nacher et al. 1999a); at this time, microglia transitorily disappears from the lesioned areas (Lopez-Garcia et al. 1994). Then, one to two weeks after the lesion, an exuberant population of microglia appears throughout the regenerating parenchyma (Nacher et al. 1999b). Thus, in the medial cortex the removal of degenerated neuronal debris and the reparative-regenerative overlap in time.

Using cytochemical methods it is possible to follow the evolution of the zinc positive presynaptic boutons emitted by the medial cortex neurones (Fig. 7). Although a fraction of zinc positive boutons remains unaffected or even appears hypertrophied after the 3AP lesion, the overwhelming majority of zinc positive boutons show damage symptoms. Most zinc positive boutons appear swollen and a little fraction of them (less that 5\%) appears as dark boutons with a highly condensed cytoplasm. In any case, most synaptic contacts are lost, resulting in a dramatic decrease of the synaptic density in both the zinc positive and the zinc negative areas of the lizard cortex (Fig. 7C). Very soon, as neuronal regeneration proceeds, there is a progressive increment in the density of synaptic contacts until reaching normal values in the zinc negative areas (Fig. 7 $\mathrm{D}-\mathrm{E})$; nevertheless, one month after the lesion the zinc positive zones only have recovered about $80 \%$ of the initial synaptic density (unpublished).

Perhaps the most exciting aspect in the regenerative process is the fact that it takes place in the adult lizard brain. Although the residual "sulcus", lining the medial cortex of adult- aged lizards is almost atrophic, as deduced from the normal rate of tritiated thymidine incorporation (Lopez-Garcia et al. 1988b, Lopez-Garcia et al. 1988c) it can still be activated after $3 \mathrm{AP}$ lesion and produce thousands 


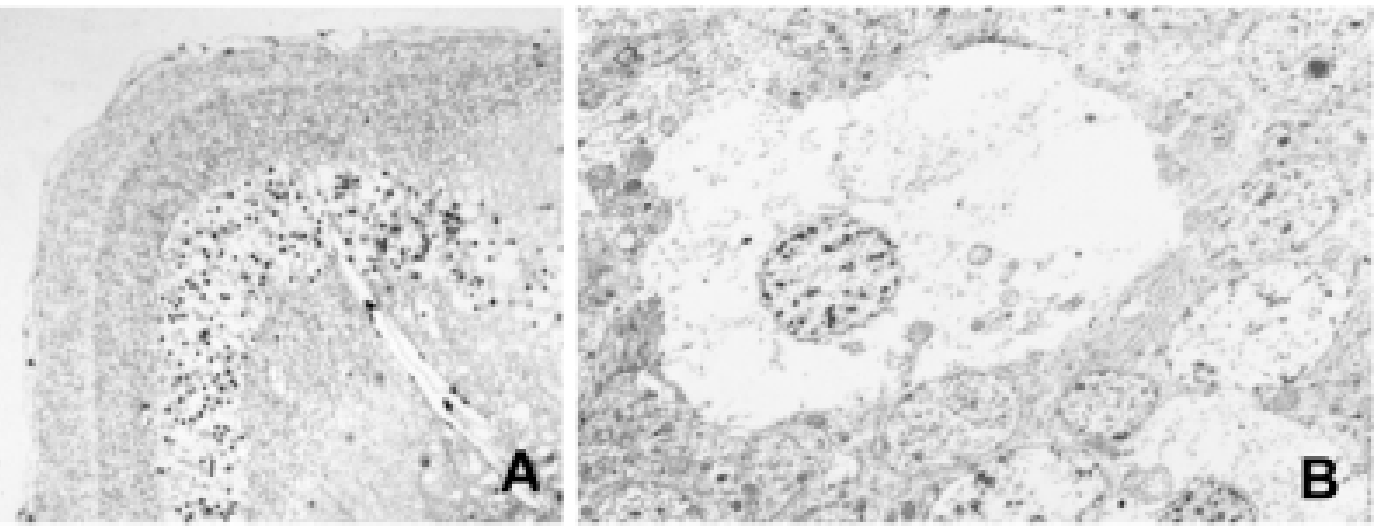

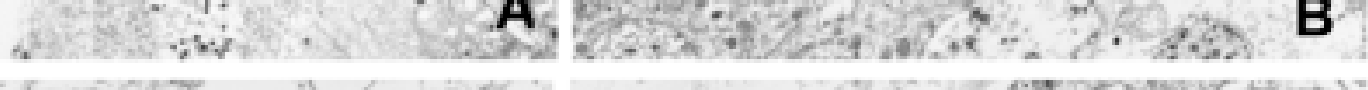

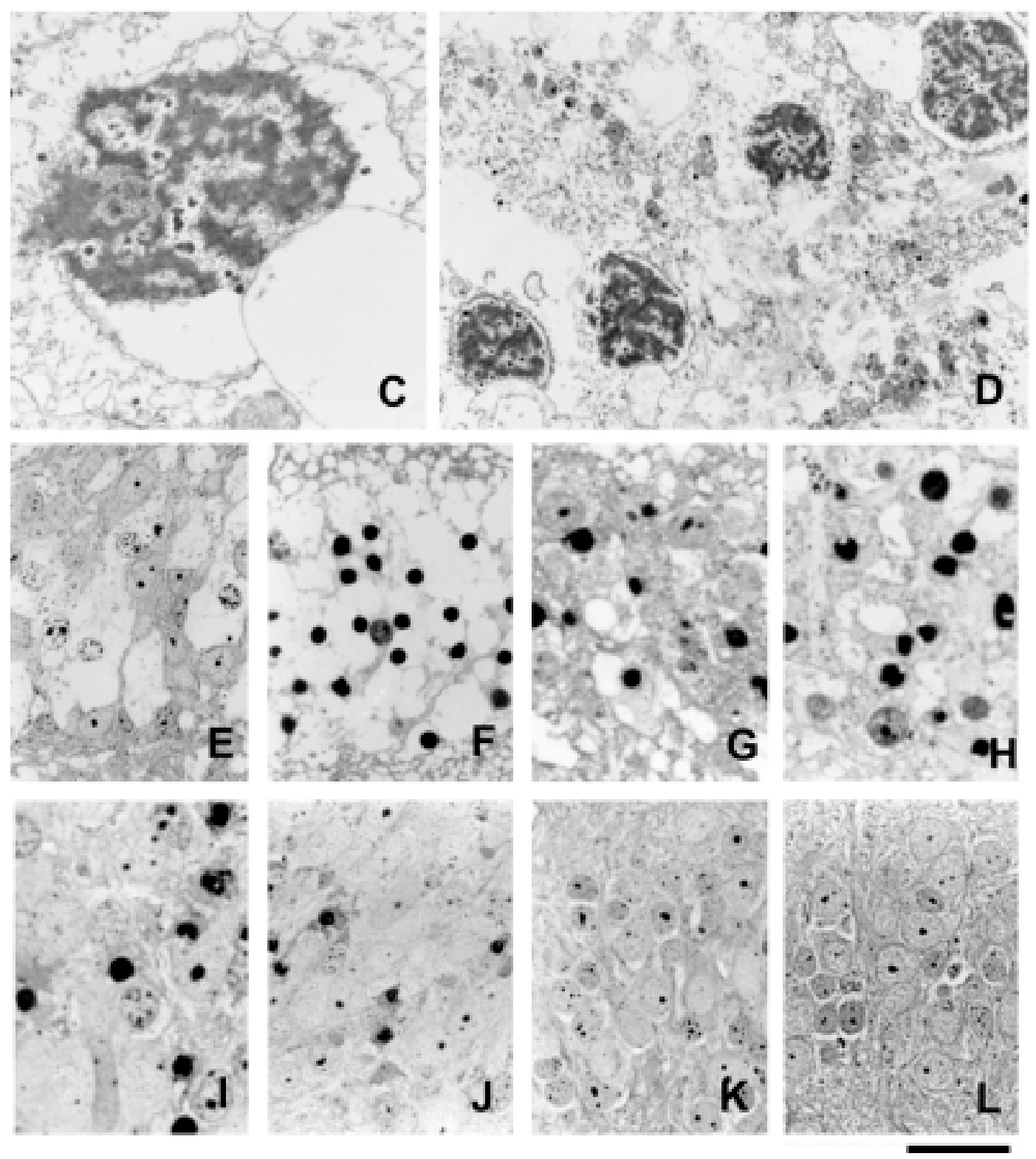


Fig. 5 - The 3-acetylpiridine lesion and subsequent regeneration A: Semithin section of the medial cortex of a lizard subjected to an intraperitoneal injection of 3-acetylpiridine (3AP) one day before sacrifice; note the dramatic density of pyknotic nuclei in the cell layer and the plexiform layers with oedematous appearance. B: Ultrathin section showing a swollen neuronal soma and its nucleus with condensed chromatin (twelve hours after 3AP injection). C-D: Idem, aspects of the medial cortex cell layer neurones four days after 3AP injection showing nuclei with condensed chromatin and dramatic swelling of the perinuclear membranous cistern. E-L: Semithin sections of the medial cortex cell layer of lizards sacrificed 12 hours (E), 1 day (F), 4 days (G), 10 days (H), 18 days (I), 34 days (J), 90 days $(\mathrm{K})$ and 180 days (L); observe that the density of pyknotic nuclei decreases after increasing days of survival and the almost normal histological appearance of the medial cortex cell layer after one month of survival and beyond. (Scale bar represents $100 \mu \mathrm{m}$ in $\mathrm{A}, 3 \mu \mathrm{m}$ in B and $\mathrm{D}, 1 \mu \mathrm{m}$ in $\mathrm{C}$ and $10 \mu \mathrm{m}$ in $\mathrm{E}-\mathrm{L})$.

of new neurones that regenerate the medial cortex (Molowny et al. 1995).

\section{FINAL COMMENT ON NEURONAL REGENERATION}

As we have seen, the sulcus septoarchicorticalis of the lizard medial cortex and the tertiary matrix zone of the fascia dentata in the mammalian hippocampus share common ontogenetical, structural and phylogenetical properties that may be predictory of similar properties concerning neuronal regeneration; i.e., those of the lizard medial cortex could be applied for the mammalian fascia dentata and viceversa.

An example in this context was the "reactive neurogenesis" after specific lesion of the lizard medial cortex (Molowny et al. 1995). A similar highly regulated mitotic response was found in rodents after seizures inducing lesion and apoptosis of dentate granule neurones (Bengzon et al. 1997, Parent et al. 1997). Enhanced neurogenesis is also elicited by kindling (Scott et al. 1998) by electroconvulsive shock therapy (Madsen et al. 2000, Scott et al. 2000) transient ischemia (Kee et al. 2001, Liu et al. 1998) or any brain injury leading to seizures (Nakagawa et al. 2000, Pollard et al. 1994, Sloviter et al. 1996, Yoshimura et al. 2001). In all these cases neurogenesis appears to be triggered by the specific lesion/injury of the fascia dentata, a phenomenon previously demonstrated in the medial cerebral cortex of lizards several years before (Molowny et al. 1995), thus validating the lizard cerebral cortex as a good experimental model.
With the limitations inherited from the phylogenetic distance, the regenerative phenomena in the lizard medial cortex may, however, provide some optimism regarding the hypothetical regenerative abilities of the mammalian brain. As such, the medial cortex of lizards is a useful model to study regenerative mechanisms which may apply to the mammalian hippocampus.

Finally it is necessary to notice some limits for neuronal regeneration; for instance, in lizards, it does not occur in winter. The explanation is that winter-low temperature prevents migration of newly generated neurones (Ramirez et al. 1997). Additionally, winter short daylight periods decreases the proliferating activity of ependymal-stem cells to avoid tumor-like accumulation of cells close to the ependyma. Although mammals are homeotherm and do not suffer these dramatic seasonal changes, the winter-summer imbalance hormone levels in lizards may give us good information regarding neuronal regeneration.

\section{ACKNOWLEDGMENTS}

This study has been supported by Grants PM9701104 and FIS 01/0096-01 from the Spanish Government.

\section{RESUMO}

O córtex cerebral de lagartos, uma área homóloga à fascia dentata hipocampal, exibe neurogênese pós-natal prolongada, isto é, o epêndima do córtex medial prolifera e dá origem a neurônios imaturos, que migram para a 

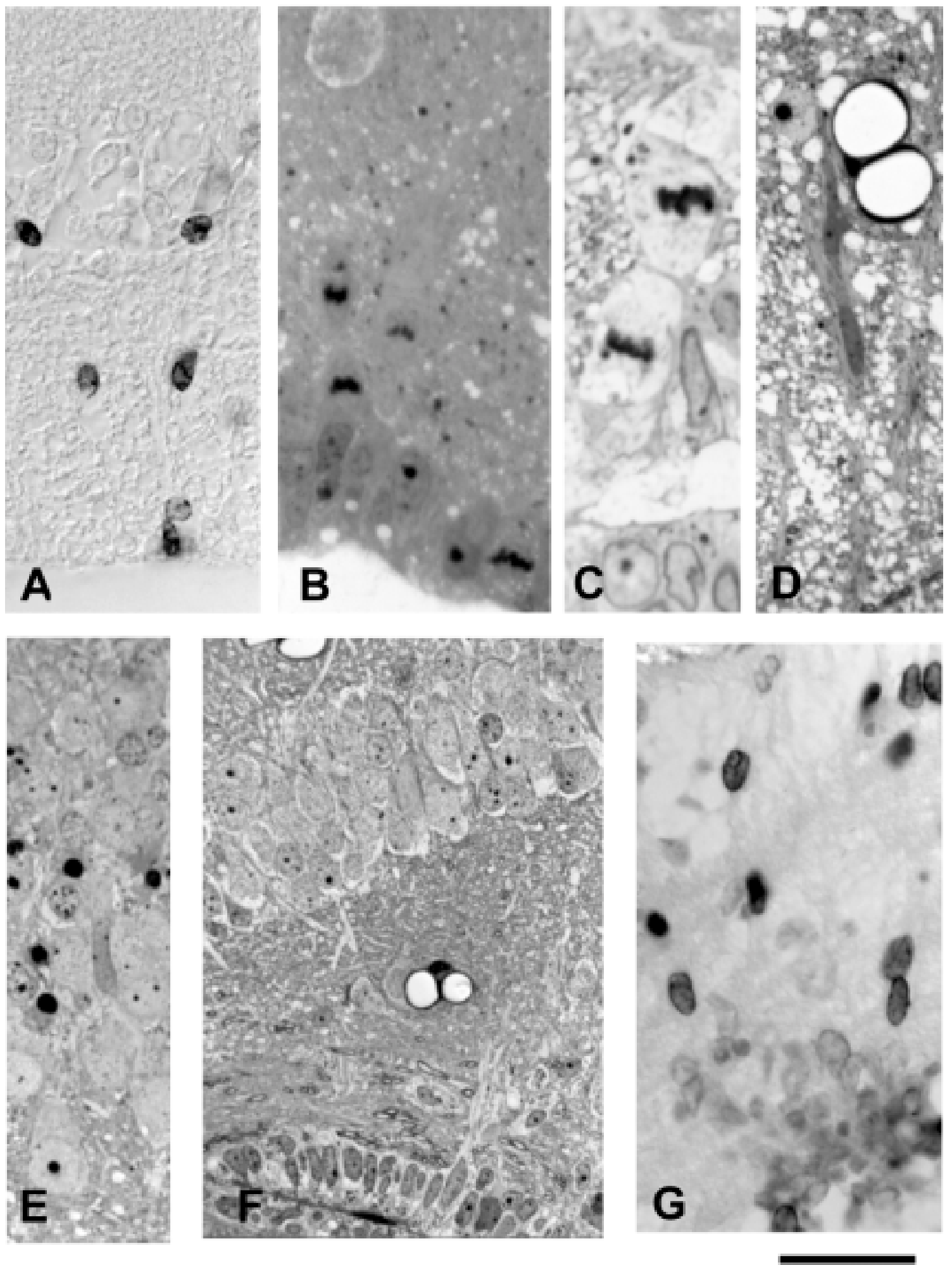
Fig. 6 - The mitotic regulated response after 3-acetylpiridine lesion. A: 5'-bromodeoxiuridine (5'-BrDu) immunostained medial cortex section of a 3AP lesioned lizard to which an injection of 5'-BrDu was delivered the day fourth after the lesion and sacrificed five days later; observe the presence of labelled nuclei both in the ependyma, in the inner plexiform layer and in the lesioned cell layer. B-C: Mitotic figures in the ependyma and radially oriented in the inner plexiform layer of 3AP lesioned lizards ten days after the lesion. D: migratory cells longitudinally arranged in the inner plexiform layer of the medial cortex of a 3AP lesioned lizard, 15 days after the lesion. E: medial cortex cell layer of a 3AP lesioned lizard, 18 days after the lesion, showing presumably just arrived fusiform nuclei. F: Semithin section of the medial cortex and its subjacent ependymary sulcus of a 3AP lesioned lizard, six months after the lesion; observe the healthy normal histological appearance. G: 5'-BrDu immunostained organotypic cultured medial cortex slice taken from a 3AP lesioned lizard to which an injection of 5'-BrDu was delivered the day fourth after the lesion, two days later the lizard was sacrificed, and the brain slice maintained for a week in culture; observe the similarities with picture A, i.e., abundant labelled nuclei in the presumed ependymary sulcus and the radially dispersed appearance until reaching the presumed medial cortex cell layer. (Scale bar represents $50 \mu \mathrm{m}$ in $\mathrm{A}, 40 \mu \mathrm{m}$ in B, D, E and G, $30 \mu \mathrm{m}$ in C and $70 \mu \mathrm{m}$ in F).

camada celular. Nesta camada, neurônios recrutados se diferenciam e dão origem a axônios, ricos em zinco, que se projetam para as demais áreas corticais, do que resulta um crescimento contínuo do córtex medial e sua projeção axonal. Isto acontece por toda a vida do lagarto, mesmo em animais adultos, o que permite uma de suas características mais importantes: a regeneração neuronal.

Experimentos em nosso laboratório demonstraram que uma lesão química do córtex medial (afetando até 95\% de seus neurônios) resulta em uma cascata de eventos: inicialmente, morte celular e retração dendro-dendrítica maciças, seguidas de proliferação neuroblasto-ependimária e subseqüente neo-histogênese e regeneração de um novo córtex medial, indistingüível de um normal, não danificado. Ao que saibamos, este é o único caso de regeneração de uma estrutura nervosa central por produção de novos neurônios e neo-histogênese em amniotas. Portanto, o córtex cerebral do lagarto é um bom modelo para estudar a regeneração de neurônios e os fatores complexos que regulam os seus eventos neurogenéticos, migratórios e de neo-sinaptogênese.

Palavras-chave: cortex medial, hipocampo, neurogênese pós-natal, células-tronco, zinco, regeneração.

\section{REFERENCES}

Altman J. 1969. Autoradiographic and histologic studies of postnatal neurogenesis. IV. Cell proliferation and migration in the anterior forebrain, with special sto persisting neurogenesis in the olfactory bulb. J Comp
Neurol 137: 433-458

Altman J ANd Bayer SA. 1990. Mosaic organization of the hippocampal neuroepithelium and the multiple germinal sources of dentate granule cells. J Comp Neurol 301: 325-342.

BAYER SA. 1980. Development of the hippocampal region in the rat. I. Neurogenesis examined with $3 \mathrm{H}-$ thymidine autoradiography. J Comp Neurol 190: 87-114.

BAYER SA. 1982. Changes in the total number of dentate granule cells in juvenile and adult rats: a correlated volumetric and $3 \mathrm{H}$-thymidine autoradiographic study. Exp Brain Res 3: 315-323.

Bayer SA, Yackel JW and Puri PS. 1982. Neurons in the dentate gyrus granular layer substantially increase during juvenile and adult life. Science 216: 890-892.

Bengzon J, Kokaia Z, Elmér E, Nanobashvili A, KoKaia M and Lindvall O. 1997. Apoptosis and proliferation of dentate gyrus neurons after single and intermittent limbic seizures. Proc Natl Acad Sci USA 94: 10432-10437.

Bernabeu A, Martinez-Guijarro FJ, Luis de La Iglesia JA AND Lopez-Garcia C. 1994. An axosomatic and axodendritic multipolar neuron in the lizard cerebral cortex. J Anat 184: 567-582

BERSTEIN JJ. 1964. Relation of spinal cord regeneration to age in adult goldfish. Exp. Neurol 9: 161-174.

Bruce LL AND Butler AB. 1984. Telencephalic connections in lizards. I. Projections to cortex. J Comp Neurol 229: 585-601. 

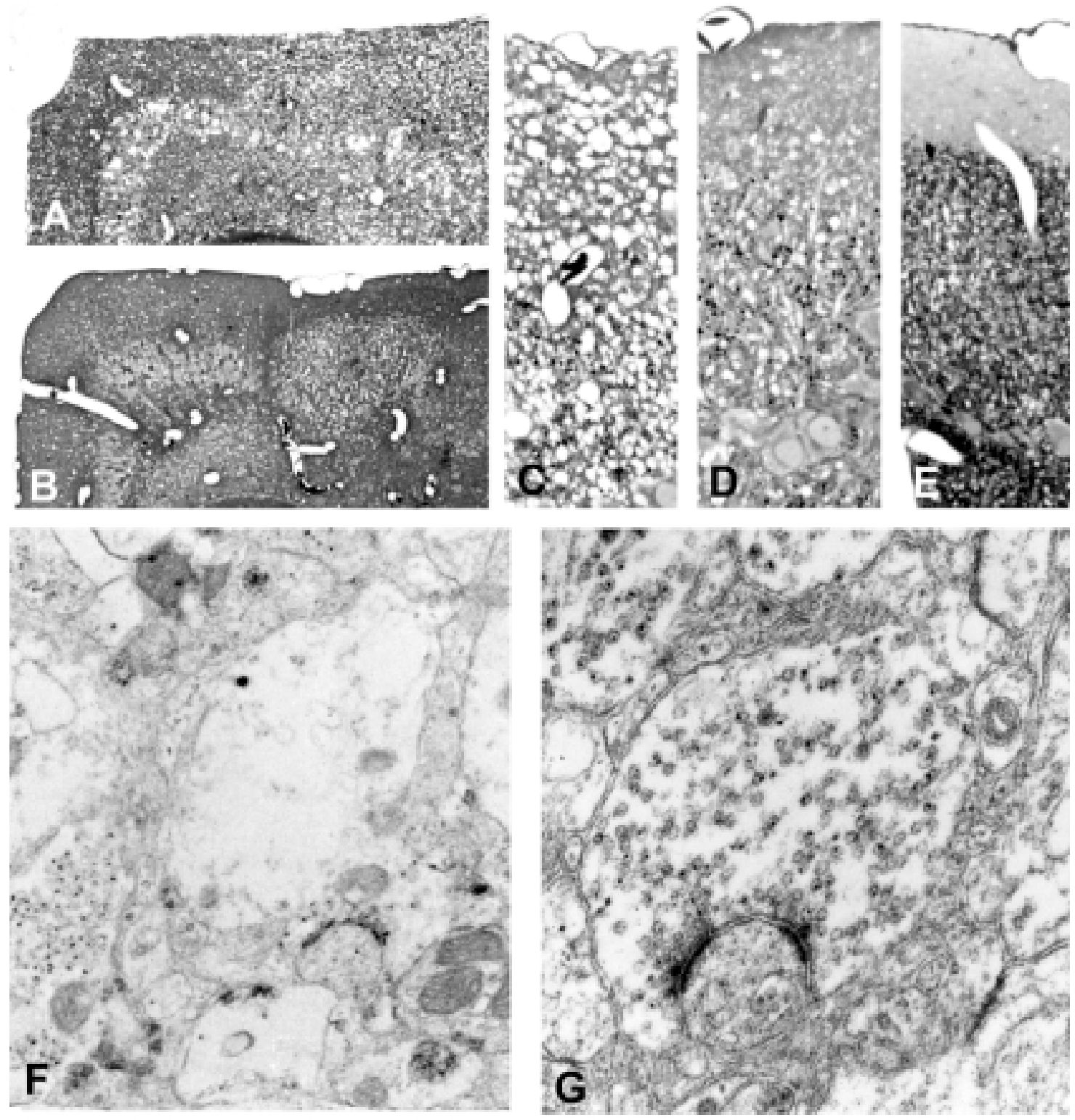

Fig. 7 - Lesion and regeneration of the medial cortex zinc positive axonal projection. A: Semithin section of the medial cortex of a lizard 1 day after 3AP injection; observe the dramatic swelling suffered by the cell layer and the plexiform layers (both zinc positive and zinc negative strata). B: Idem, four days after 3AP injection; observe that the oedematous appearance has disappeared from the zinc negative areas but in the zinc positive ones plenty swollen dendritic and axonal profiles still appear. C-E: Aspect of the dorsomedial outer plexiform layer in lizards sacrificed 1 day (C), 4 days (D) and 34 days (E) after 3AP lesion in Timm stained semithin sections; observe the absence of Timm reaction one day after lesion, the presence of some puncta-like positive spots four days after lesion (D) and the abundance of them in the almost completely regenerated area 34 days afterwards (E). F-G: Ultrathin section of zinc positive boutons in the outer plexiform layer of the dorsomedial cortex four days (F) and 10 days (G) after 3AP lesion; observe that on day 4 after lesion the zinc positive bouton appears swollen but still making a synaptic contact with a dendritic spine and that on day 10 after lesion it displays a completely normal appearance. (Scale bar represents $150 \mu \mathrm{m}$ in A and B, $40 \mu \mathrm{m}$ in C-E, $5 \mu \mathrm{m}$ in $\mathrm{F}$ and $3 \mu \mathrm{m}$ in $\mathrm{G}$ ). 
Caetano MH, Castanet J and Crespo EG. 1986. Estimation a l'aide de la squelettchronologie de l'age de Podarcis hispanica, (Steindnacher, 1870), Sauria, Lacertidae, provenant d'una population portugaise. Rev Suisse Zool 93: 117-127.

Cameron HA, Woolley CS, McEwen BS and Gould E. 1993. Differentiation of newly born neurons and glia in the dentate gyrus of the adult rat. Neuroscience 56: $337-344$.

CoRwIN JT. 1985. Perpetual production of hair cells and maturational changes in the hair cell ultrastructure accompany postembryonic growth in an amphibian ear. Proc Natl Acad Sci USA 82: 3911-3915.

Davila JC, de la Calle A, Gutierrez A, Megias M, Andreu MJ ANd Guirado S. 1991. Distribution of neuropeptide Y (NPY) in the cerebral cortex of the lizards Psammodromus algirus and Podarcis hispanica: Co-localization of NPY, somatostatin, and GABA. J Comp Neurol 308: 397-408.

Davila JC, Megias M, Andreu MJ, Real MA and GUIRADO S. 1995. NADPH diaphorase-positive neurons in the lizard hippocampus: a distinct subpopulation of GABAergic interneurons. Hippocampus 5: 60-70.

DE La Iglesia JAL and Lopez-Garcia C. 1997a. A Golgi study of the principal projection neurons of the medial cortex of the lizard Podarcis hispanica. $\mathrm{J}$ Comp Neurol 385: 528-564.

DE La Iglesia JAL and Lopez-Garcia C. 1997b. A Golgi study of the short-axon interneurons of the cell layer and inner plexiform layer of the medial cortex of the lizard Podarcis hispanica. J Comp Neurol 385: 565-598.

DE La Iglesia JAL, Martinez-GuiJarro FJ AND Lopez-Garcia C. 1994. Neurons of the medial cortex outer plexiform layer of the lizard Podarcis hispanica: Golgi and immunocytochemical studies. J Comp Neurol 341: 184-203.

DE LANGe SJ. 1911. Das Vorderhirn der Reptilien. Folia Neuro-Biol Leitzig 5: 548-597.

ECKENHOFF MF AND RAKIC P. 1984. Radial organization of the hippocampal dentate gyrus: a Golgi, ultrastructural, and immunocytochemical analysis in the developing rhesus monkey. J Comp Neurol 223: $1-21$.
ECKENHOFF MF AND RAKIC P. 1988. Nature and fate of proliferative cells in the hippocampal dentate gyrus during the life span of the rhesus monkey. J Neurosci 8: 2729-2747.

EDINGER L. 1896. Untersuchungen uber die vergleichende Anatomie des Gehirn. III. Neue Studien uber das Vordergehirn der Reptilien. Abh Senckenb Naturforsch Ges 19: 313-388.

Elliot-Smith G. 1903. On the morphology of the cerebral commissures in the Vertebrates, with special reference to an aberrant commissure found in the forebrain of certain Reptiles. Trans Linn Soc London 8: 455-500.

Font E, Garcia-Verdugo JM, Martinez-Guijarro FJ, Alcantara S and Lopez-Garcia C. 1989. Neurobehavioral effects of 3-acetylpyridine in the lizard Podarcis hispanica. Eur J Neurosci 2S: 148.

Font E, García-Verdugo JM, Alcántara S AND Lopez-Garcia C. 1991. Neuron regeneration reverses 3-acetylpyridine-induced cell loss in the cerebral cortex of adult lizards. Brain Res 551: 230-235.

Garcia-Verdugo JM, Berbel P and Lopez-Garcia C. 1981. A Golgi and electron microscopic study of the ependymal cells of the cerebral cortex of the lizard Lacerta galloti. Trab Inst Cajal Inv Biol 72: 269-278.

Garcia-Verdugo JM, Farinas I, Molowny A And LoPEZ-GARCIA C. 1986. Ultrastructure of putative migrating cells in the cerebral cortex of Lacerta galloti. J Morphol 189: 189-197.

Gould E, Beylin A, Tanapat P, Reeves A and Shors TJ. 1999. Learning enhances adult neurogenesis in the hippocampal formation. Nat Neurosci 2: 260265.

Hastings NB AND Gould E. 1999. Rapid extension of axons into the CA3 region by adult-generated granule cells. J Comp Neurol 413: 146-54.

Holder N ANd Clarke JD. 1988. Is there a correlation between continuous neurogenesis and directed axon regeneration in the vertebrate nervous system? Trends Neurosci 11: 94-99.

Hoogland PV and Vermeulen-Vanderzee E. 1995. Efferent connections of the lateral cortex of the lizard Gekko gecko: Evidence for separate origins of medial and lateral pathways from the lateral cortex to the hypothalamus. J Comp Neurol 352: 469-480. 
JOHNSON EM JR AND DeCKWERTH TL. 1993. Molecular mechanisms of developmental neuronal death. Annu Rev Neurosci 16: 31-46.

JoHnSTON JB. 1916. Evidence of a motor pallium in the forebrain of reptiles. J Comp Neurol 26: 481.

KAPLAN MS AND BELL DH. 1983. Neuronal proliferation in the 9-month-old rodent- radioautographic study of granule cells in the hippocampus. Exp Brain Res 52: $1-5$.

Kappers ACU and Theunissen WF. 1908. Die Phylogenese des Rhinencephalon des Corpus striatum und der Vorderhirnkommissuren. Folia Neurobiol 1: $173-288$

Kee NJ, Preston E and Wojtowicz JM. 2001. Enhanced neurogenesis after transient global ischemia in the dentate gyrus of the rat. Exp Brain Res 136: $313-320$

KIRSCHE W. 1967. Uber postembryonale Matrixzonen im Gehirn verschiedener Vertebraten und deren Beziehung zur Hirnbauplanlehre. Z Mikros Anat Forsch 77: 313-406.

KoRnack DR and RaKic P. 1999. Continuation of neurogenesis in the hippocampus of the adult macaque monkey. Proc Natl Acad Sci USA 96: 5768-5773

LACEY DJ. 1978. The organization of the hippocampus of the Fence lizard: a light microscopic study. J Comp Neurol 182: 247-264.

Liu JL, Solway K, Messing RO and Sharp FR. 1998. Increased neurogenesis in the dentate gyrus after transient global ischemia in gerbils. J Neurosci 18: 77687778 .

Lopez-Garcia C and Martinez-GuiJarro FJ. 1988. Neurons in the medial cortex give rise to Timmpositive boutons in the cerebral cortex of lizards. Brain Res 463: 205-217.

Lopez-Garcia C, Soriano E, Molowny A, GarciaVerdugo JM, Berbel PJ ANd Regidor J. 1983a. The Timm-positive system of axonic terminals of the cerebral cortex of Lacerta. In: GrisOLIA S, GUERRI C, Samson F, Norton S and Reinoso-Suarez F, eds. Ramon y Cajal's Contributions to the Neurosciences. Amsterdam: Elsevier Sci. Pub., 137-148.

Lopez-Garcia C, Molowny A and Perez-Clausell J. 1983b. Volumetric and densitometric study in the cerebral cortex and septum of a lizard (Lacerta gal- loti) using the Timm method. Neurosci Lett 40: 13 18

Lopez-Garcia C, Tineo PL and Del-Corral J. 1984. Increase of the neuron number in some cerebral cortical areas of a lizard, Podarcis hispanica, (Steind., 1870), during postnatal periods of life. J Hirnforsch 25: $255-259$.

Lopez-Garcia C, Martinez-Guijarro FJ, Berbel P ANd Garcia-Verdugo JM. 1988a. Long-spined polymorphic neurons of the medial cortex of lizards: a Golgi, Timm, and electron-microscopic study. J Comp Neurol 272: 409-423.

Lopez-Garcia C, Molowny A, Garcia-Verdugo JM AND FERrER I. 1988b. Delayed postnatal neurogenesis in the cerebral cortex of lizards. Brain Res 471: 167-174.

Lopez-Garcia C, Molowny A, Rodriguez-Serna R, Garcia-Verdugo JM and Martinez-GuiJarro FJ. 1988c. Postnatal development of neurons in the telencephalic cortex of lizards. In: ScHWERDTFEgER WK and SmeEts W, eds. The forebrain of reptiles: Current concepts of structure and function. Basel: Karger, 122-130.

Lopez-Garcia C, Molowny A, Garcia-Verdugo JM, Martinez-Guijarro FJ and Bernabeu A. 1990a. Late generated neurons in the medial cortex of adult lizards send axons that reach the Timm-reactive zones. Dev Brain Res 57: 249-254.

Lopez-Garcia C, Molowny A, Garcia-Verdugo JM, Martinez-Guijarro FJ, Font E and Alcantara S. 1990b. Neurogenesis postnatal tardia y regeneracion en la corteza cerebral de la lagartija comun. Biologia del Desenvolupament 8: 183-192.

Lopez-Garcia C, Molowny A, Martinez-Guijarro FJ, Blasco-IBañez JM, DE La Iglesia JAL, BERNABEu A ANd Garcia-Verdugo JM. 1992. Lesion and regeneration in the medial cerebral cortex of lizards. Histol Histopath 7: 725-746.

Lopez-Garcia C, Nacher J, Castellano B, De La Iglesia JAL and Molowny A. 1994. Transitory disappearance of microglia during the regeneration of the lizard medial cortex. Glia 12: 52-61.

Lurie DI AND Selzer ME. 1991. Axonal regeneration in the adult lamprey spinal cord. J Comp Neurol 306: 409-416. 
LUSKIN MB. 1993. Restricted proliferation and migration of postnatally generated neurons derived from the forebrain subventricular zone. Neuron 11: 173189.

Madsen TM, Treschow A, Bengzon J, Bolwig TG, LindVall O AND Tingström A. 2000. Increased neurogenesis in a model of electroconvulsive therapy. Biol Psychiatry 47: 1043-1049.

Martinez-Garcia F, Amiguet M, Olucha F and Lopez-Garcia C. 1986. Connections of the lateral cortex in the lizard Podarcis hispanica. Neurosci Lett 63: 39-44.

Martinez-GuiJarro FJ. 1982. Morfologia y ultraestructura de las dendritas apicales de las neuronas bipiramidales localizadas en el cortex dorsomedial de lacertidos. Minor Thesis. University of Valencia.

Martinez-GuiJarro FJ. 1985. Organizacion de las areas dorsomedial y dorsal de la corteza cerebral de Podarcis hispanica (Steindachner, 1870). Doctoral Thesis, Univ. Valencia.

Martinez-Guijarro FJ and Freund TF. 1992. Distribution of GABAergic interneurons immunoreactive for calretinin, calbindin $\mathrm{D} 28 \mathrm{~K}$, and parvalbumin in the cerebral cortex of the lizard Podarcis hispanica. J Comp Neurol 322: 449-460.

Martinez-Guijarro FJ, Berbel PJ, Molowny A and LopeZ-Garcia C. 1984. Apical dendritic spines and axonic terminals in the bipyramidal neurons of the dorsomedial cortex of lizards (Lacerta). Anat Embryol 170: 321-326.

Martinez-Guijarro FJ, Molowny A and LopezGarcia C. 1987. Timm-staining intensity is correlated with the density of Timm- positive presynaptic structures in the cerebral cortex of lizards. Histochemistry 86 : 315-319.

Martinez-Guijarro FJ, Desfilis E and Lopez-Garcia C. 1990. Organization of the dorsomedial cortex in the lizard Podarcis hispanica. In: ScHWERdTFEGER WK AND GERMroth P, eds. The forebrain in nonmammals. New aspects of structure and development. Berlin: Springer-Verlag, 77-92.

Martinez-Guijarro FJ, Soriano E, Del Rio JA And Lopez-Garcia C. 1991a. Parvalbumin-immunoreactive neurons in the cerebral cortex of the lizard $\mathrm{Po}$ darcis hispanica. Brain Res 547: 339-343.
Martinez-Guijarro FJ, Soriano E, Del Rio JA and LOPEZ-GarCIA C. 1991b. Zinc-positive boutons in the cerebral cortex of lizards show glutamate immunoreactivity. J Neurocytol 20: 834-843.

Molowny A and Lopez-Garcia C. 1978. Estudio citoarquitectonico de la corteza cerebral de reptiles. III. Localizacion histoquimica de metales pesados y definicion de subregiones Timm-positivas en la corteza de Lacerta, Chalcides, Tarentola y Malpolon. Trab Inst Cajal Inv Biol 70: 55-74.

Molowny A, Martinez-Calatayud J, Juan MJ, Martinez-GuiJarro FJ and Lopez-Garcia C. 1987. Zinc accumulation in the telencephalon of lizards. Histochemistry 86: 311-314.

Molowny A, Nacher J And Lopez-Garcia C. 1995. Reactive neurogenesis during regeneration of the lesioned medial cerebral cortex of lizards. Neuroscience 68: $823-836$.

Nacher J, Ramirez-Castillejo C, Palop JJ, Molowny A, DE LA Iglesia JAL AND Lopez-Garcia C. 1999a. Radial glia and cell debris removalduring lesion-regeneration of the lizard medial cortex. Histol Histopath 14: 89-101.

Nacher J, Ramirez-Castillejo C, Artal P, Molowny A AND Lopez-Garcia C. 1999b. Microglial cells during the lesion-regeneration of the lizard medial cortex. Histol Histopath 14: 103-117.

Nakagawa E, Aimi Y, Yasuhara O, Tooyama I, Shimada M, McGeer PL and Kimura H. 2000. Enhancement of progenitor cell division in the dentate gyrus triggered by initial limbic seizures in rat models of epilepsy. Epilepsia 41: 10-18.

Olucha F, Martinez-Garcia F, Poch L, SchwerdtFEGER WK AND LoPeZ-Garcia C. 1988. Projections from the medial cortex in the brain of lizards: correlation of anterograde and retrograde transport of horseradish peroxidase with Timm staining. J Comp Neurol 276: 469-480.

Parent JM, Yu TW, Leibowitz RT, Geschwind DH, Sloviter RS ANd Lowenstein DH. 1997. Dentate granule cell neurogenesis is increased by seizures and contributes to aberrant network reorganization in the adult rat hippocampus. J Neurosci 17: 3727-3738

Peñafiel A, Gutiérrez A, Martín R, PérezCañellas MM and de La Calle A. 1996. A tangential neuronal migration in the olfactory bulbs of 
adult lizards. NeuroReport 7: 1257-1260.

Perez-Cañellas M. 1989. Desarrollo postnatal tardio del sistema Timm-positivo septocortical de Chalcides sexlineatus. University of Valencia: Minor Thesis.

Perez-Sanchez F, Molowny A, Garcia-Verdugo JM AND LopeZ-Garcia C. 1989. Postnatal neurogenesis in the nucleus sphericus of the lizard, Podarcis hispanica. Neurosci Lett 106: 71-75.

Pollard H, Charriaut-Marlangue C, Cantagrel $S$, Represa A, Robain O, Moreau J and Ben-Ari Y. 1994. Kainate-induced apoptotic cell death in hippocampal neurons. Neuroscience 63: 7-18.

Rakic P AND Nowakowski RS. 1981. The time of origin of neurons in the hippocampal region of the rhesus monkey. J Comp Neurol 1: 99-128.

Ramirez C, Nacher J, Molowny A, Sanchez-SanChez F, IruRzun A and Lopez-Garcia C. 1997. Photoperiod-temperature and neuroblast proliferation-migration in the adult lizard cortex. NeuroReport 8: 2337-2342.

Ramon and Cajal P. 1917. Nuevo estudio del encefalo de los reptiles. Trab Lab Inv Biol Univ Madrid 15: 83-99.

Rickmann M, Amaral DG and Cowan WM. 1987. Organization of radial glial cells during the development of the rat dentate gyrus. J Comp Neurol 264: 449-479.

RodrigueZ-SERna R. 1987. Desarrollo postnatal del sistema Timm-positivo del telencefalo de Podarcis hispanica, (Steindachner,1870).University of Valencia: Minor Thesis.

Rutishauser U and Landmesser L. 1996. Polysialic acid in the vertebrate nervous system: a promoter of plasticity in cell-cell interactions. Trends Neurosci 19: 422-427.

SCHRENER TW AND SChrener A. 1982. Intraspecific variation in home-range size in some Anolis lizards. Ecology 63: 809-823.

SchWerdtFeger WK AND Lopez-Garcia C. 1986. GABAergic neurons in the cerebral cortex of the brain of a lizard (Podarcis hispanica). Neurosci Lett 68: $117-121$.

Scott BW, Wang s, Burnham WM, de Boni U and Wostowicz JM. 1998. Kindling-induced neuroge- nesis in the dentate gyrus of the rat. Neurosci Lett 248: 73-76.

Scott BW, Wojtowicz JM and Burnham VM. 2000 Neurogenesis in the dentate gyrus of the rat following electroconvulsive shock seizures. Exp Neurol 165: 231-236.

Seki T And ARai Y. 1991. The persistent expression of a highly polysialylated NCAM in the dentate gyrus of the adult rat. Neurosci Res 12: 503-513.

SeKI T and Arai Y. 1993. Highly polysialylated neural cell adhesion molecule (NCAM- H) is expressed by newly generated granule cells in the dentate gyrus of the adult rat. J Neurosci 13: 2351-2358.

Seki T and Arai Y. 1999. Temporal and spacial relationships between PSA-NCAM-expressing, newly generated granule cells, and radial glia-like cells in the adult dentate gyrus. J Comp Neurol 410: 503513.

Shimizu I, Oppenheim RW, O'Brien M and ShneiderMAN A. 1990. Anatomical and functional recovery following spinal cord transection in the chick embryo. J Neurobiol 21: 918-937.

Shors TJ, Miesegaes G, Beylin A, Zhao MR, Rydel T AND Gould E. 2001. Neurogenesis in the adult is involved in the formation of trace memories. Nature 410: 372-376.

Sloviter RS, Dean E, Sollas AL and Goodman JH. 1996. Apoptosis and necrosis induced in different hippocampal neuron populations by repetitive perforant path stimulation in the rat. J Comp Neurol 366: 516-533.

Stanfield BB and TRICE JE. 1988. Evidence that granule cells generated in the dentate gyrus of adult rats extend axonal projections. Exp Brain Res 72: 399406.

Tineo PL, Planelles MD and Del-Corral J. 1987. Modifications in cortical ependyma of the lizard, $P O$ darcis hispanica, during postnatal development. J Hirnforsch 28: 485-489.

Yoshimura S, takagi Y, Harada J, Teramoto T, Thomas SS, Waeber C, BaKowsKa JC, BreakeFIELD XO AND Moskowitz MA. 2001. FGF-2 regulation of neurogenesis in adult hippocampus after brain injury. Proc Natl Acad Sci USA 98: 58745879. 